\title{
Identification of basepairs within Tn5 termini that are critical sfor H-NS binding to the transpososome and regulation of $\operatorname{Tn} 5$ transposition
}

\author{
Crystal R Whitfield, Brian H Shilton and David B Haniford
}

\begin{abstract}
Background: The H-NS protein is a global regulator of gene expression in bacteria and can also bind transposition complexes (transpososomes). In Tn5 transposition H-NS promotes transpososome assembly in vitro and disruption of the hns gene causes a modest decrease in Tn5 transposition (three- to five-fold). This is consistent with H-NS acting as a positive regulator of Tn5 transposition. Molecular determinants for H-NS binding to the Tn5 transpososome have not been determined, nor has the strength of the interaction been established. There is also uncertainty as to whether H-NS regulates Tn5 transposition in vivo through an interaction with the transposition machinery as disruption of the hns gene has pleiotropic effects on Escherichia coli, the organism used in this study.

Results: In the current work we have further examined determinants for H-NS binding to the Tn5 transpososome through both mutational studies on Tn5 termini (or 'transposon ends') and protein-protein cross-linking analysis. We identify mutations in two different segments of the transposon ends that abrogate H-NS binding and characterize the affinity of H-NS for wild type transposon ends in the context of the transpososome. We also show that $\mathrm{H}$-NS forms cross-links with the Tn5 transposase protein specifically in the transpososome, an observation consistent with the two proteins occupying overlapping binding sites in the transposon ends. Finally, we make use of the end mutations to test the idea that H-NS exerts its impact on Tn5 transposition in vivo by binding directly to the transpososome. Consistent with this possibility, we show that two different end mutations reduce the sensitivity of the Tn5 system to H-NS regulation.

Conclusions: H-NS typically regulates cellular functions through its potent transcriptional repressor function. Work presented here provides support for an alternative mechanism of H-NS-based regulation, and adds to our understanding of how bacterial transposition can be regulated.
\end{abstract}

Keywords: Tn5, H-NS, DNA transposition, Transpososome assembly, Host factor

\section{Background}

Most bacteria harbor a variety of different types of transposons [1]. While transposons can compromise genome stability through the various types of DNA rearrangements they promote, they can also confer a selective advantage to their hosts. This can come about through transposons acquiring genes that encode resistance to antibiotics and other environmental toxins, or through transposon insertion events that alter the expression of key host genes. In order for transposons and their hosts

\footnotetext{
* Correspondence: haniford@uwo.ca

* Correspondence: haniford@uwo.ca
Department of Biochemistry, University of Western Ontario, London, Ontario N6A 5C1, Canada
}

(c) 2012 Whitfield et al; licensee BioMed Central Ltd. This is an Open Access article distributed under the terms of the Creative Commons Attribution License (http://creativecommons.org/licenses/by/2.0), which permits unrestricted use, distribution, and reproduction in any medium, provided the original work is properly cited.

to coexist, transposition levels must be tightly regulated [2]. There are several examples where host proteins have been co-opted to down-regulate transposition. For instance, Dam methylase of E. coli methylates GATC sequences found in both the promoters controlling the expression of some transposase genes and in the transposon ends of several transposons. The former inhibits transposase expression and the latter inhibits transposase binding to transposon end sequences [3,4]. Other examples of host proteins that limit transposition include proteins that are global regulators of gene expression in bacteria, including IHF [5], RNaseE [6] and Hfq [7]. It is also apparent in some cases that there has been strong 
selective pressure for transposons to contain regulatory sequences for transposase genes that are suboptimal for transposase expression. For example, both Tn10 and Tn 5 have weak promoter sequences and suboptimal translation initiation regions for their transposase genes. On the other hand there are some examples where transposons appear to have co-opted host proteins to promote their transposition. Examples of such proteins include IHF, HU, H-NS, Fis, topoisomerase I, DNA gyrase and DnaA $[2,8]$.

It is often unclear as to whether host proteins directly or indirectly regulate transposition reactions. The development of in vitro transposition reactions for systems such as $\mathrm{Mu}, \mathrm{Tn} 7, \operatorname{Tn} 10$ and $\mathrm{Tn} 5$ has allowed host factors implicated as regulators of transposition reactions to be tested for their potential to directly interact with the transposition machinery. IHF, H-NS and HU are all DNA-binding proteins that have been shown to directly interact with transposition complexes in vitro $[2,8,9]$. The distinction between a direct versus an indirect regulatory pathway could be important with regard to how efficiently and quickly a transposon can respond to changing physiological conditions in the cell.

In the current work we focused on the role of H-NS in Tn5 transposition. H-NS is a highly expressed DNAbinding protein that is present in many proteobacteria [10]. H-NS binding to high affinity sites embedded within A-T rich sequences is thought to nucleate polymerization of H-NS on DNA [11]. In solution, H-NS exists predominantly as a dimer at physiological concentrations [12], but upon binding DNA H-NS forms higher order oligomers through head-to-head and tail-to-tail interactions between adjacent dimers [13]. Oligomerization of H-NS on promoter regions of genes results in gene silencing probably through exclusion of RNA polymerase [14]. HNS influences the expression of a large number of genes in E. coli and is therefore considered a global regulator of gene expression $[15,16]$. H-NS also plays an important role in lateral gene transfer in some proteobacteria as it has a propensity to silence newly acquired genes, which tend to be A-T rich, permitting bacteria to gradually integrate the new DNA into existing regulatory circuits [14].

$\mathrm{Tn} 5$ is a composite transposon made up of three antibiotic resistance genes encompassed by insertion sequences IS50-Right and IS50-Left (Figure 1A). Tn5/ IS50 is widely distributed in proteobacteria. Tn 5 and IS50 transposition is tightly regulated with events occurring at a frequency of roughly one event per element per generation in $10^{5}$ and $10^{3}$ cells, respectively. Transposition occurs predominantly through a cut-and-paste mechanism involving the formation of transposon end hairpins [17]. A high-resolution structure of the Tn5 transpososome has provided a wealth of information regarding protein-protein and protein-DNA interactions within the transpososome [18], but details still remain to be elucidated with regard to how the transpososome is assembled.

In previous work we have shown that inclusion of $\mathrm{H}-\mathrm{NS}$ in Tn5 transpososome assembly reactions resulted in incorporation of H-NS into the transpososome. Moreover, when such assembly reactions were performed under conditions where transpososome assembly was suboptimal (that is, in the presence of a DNA competitor) it was found that inclusion of H-NS greatly facilitated transpososome formation. Importantly, H-NS did not directly impact the efficiency of transposon excision when it was added to reactions containing pre-assembled transpososomes under standard conditions [9]. The positive effect of H-NS on transpososome formation could result from H-NS promoting: (1) the formation of a pre-transpososome complex (for example, a complex where a monomer of transposase binds a single transposon end); (2) the assembly of pre-transpososome complexes into transpososome; and/or (3) the stabilization of the transpososome. Consistent with H-NS acting as a positive regulator of $\operatorname{Tn} 5$ transposition it has previously been shown that $\operatorname{Tn} 5$ transposition is reduced approximately three- to five-fold in E. coli containing a disruption of the $h n s$ gene $(\Delta h n s)$ [9].

Our finding that $\mathrm{H}-\mathrm{NS}$ binds to the Tn 5 transpososome in vitro led us to perform DNA footprinting experiments in an attempt to localize the site(s) of binding. The reactivity of the transpososome DNA to hydroxyl radical cleavage was altered at three sites, which we have designated sites 1 , 2 and 3 [9] (Figure 1). Based on the transpososome crystal structure, sites 2 and 3 are the most obviously accessible sites for $\mathrm{H}-\mathrm{NS}$ binding.

In the current study we have further investigated the interaction between $\mathrm{H}-\mathrm{NS}$ and the Tn 5 transpososome by measuring the affinity of $\mathrm{H}-\mathrm{NS}$ for the Tn 5 transpososome and using site-directed mutagenesis and protein-protein cross-linking studies to define determinants for $\mathrm{H}-\mathrm{NS}$ binding to the transpososome. We have also used the information gained from site-directed mutagenesis to test the idea that $\mathrm{H}-\mathrm{NS}$ regulates $\mathrm{Tn} 5$ transposition in vivo by acting directly on the transpososome.

\section{Results}

Basepair mutations within two putative H-NS binding sites reduce the affinity of $\mathrm{H}-\mathrm{NS}$ for the Tn5 transpososome

We previously used hydroxyl radical footprinting to characterize the H-NS interaction with a Tn5 transpososome assembled with mosaic end (ME) sequences [9]; the ME is a chimeric end composed of nucleotides from both the outside (OE) and inside ends (IE) of Tn5 and is optimized for use in vitro [19]. Three potential H-NS binding sites were defined (see model in Figure 1B). In this work 


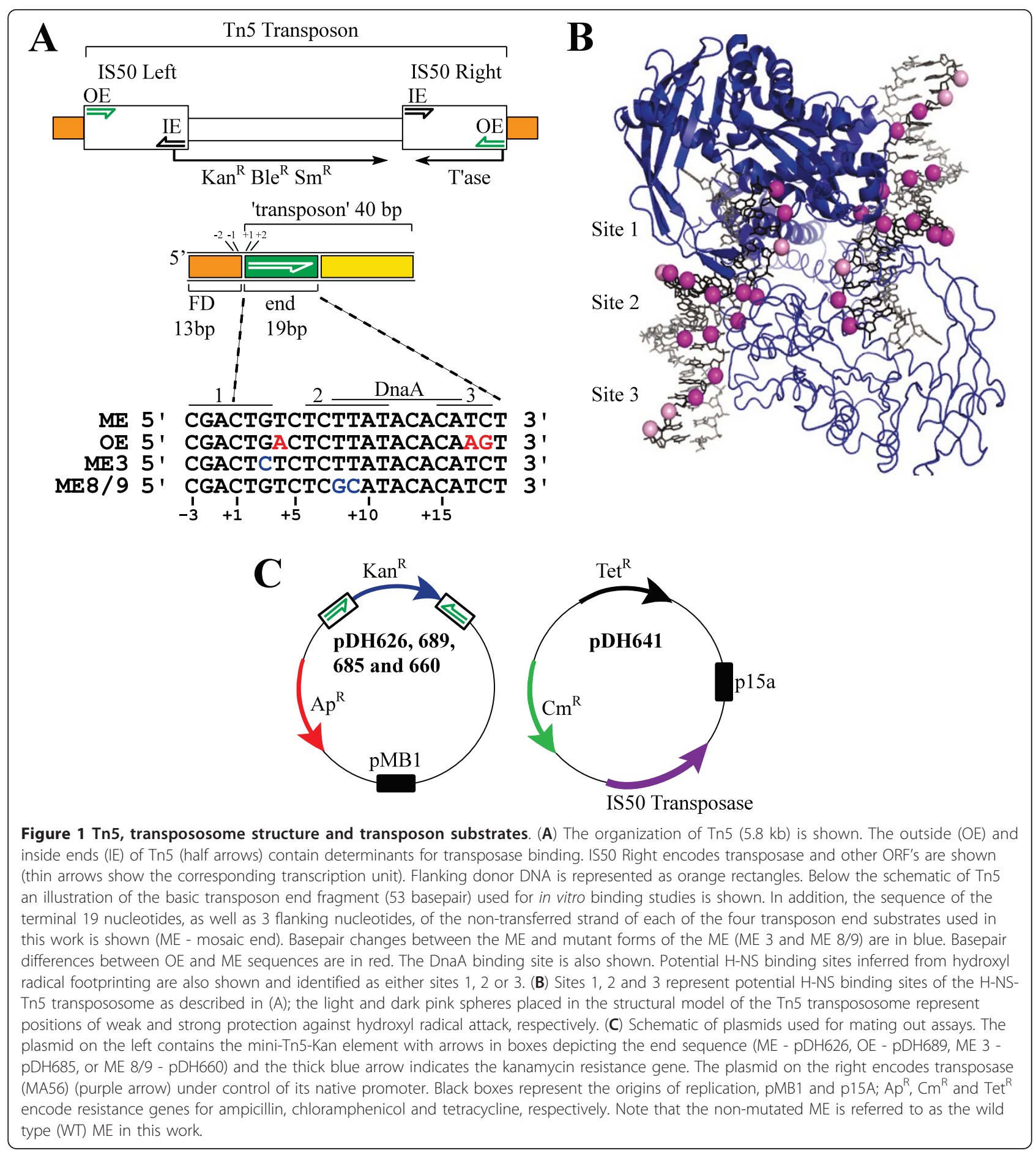

we have tested the importance of each of the three sites for H-NS binding by introducing one or more basepair mutations into these sites. As H-NS binding to ME sequences is dependent on the presence of transposase [9], we targeted residues expected not to be critical for transposase-end interactions. This greatly limited the number of mutations we tested as transposase makes extensive contacts with the transposon end DNA [18]. The three different transposon end substrates we tested for H-NS binding are shown in Figure 1A.

We used an electrophoretic mobility shift assay (EMSA) to measure the impact of the above basepair changes on incorporation of H-NS into the Tn5 transpososome. In the EMSA's shown in Figure 2 we 


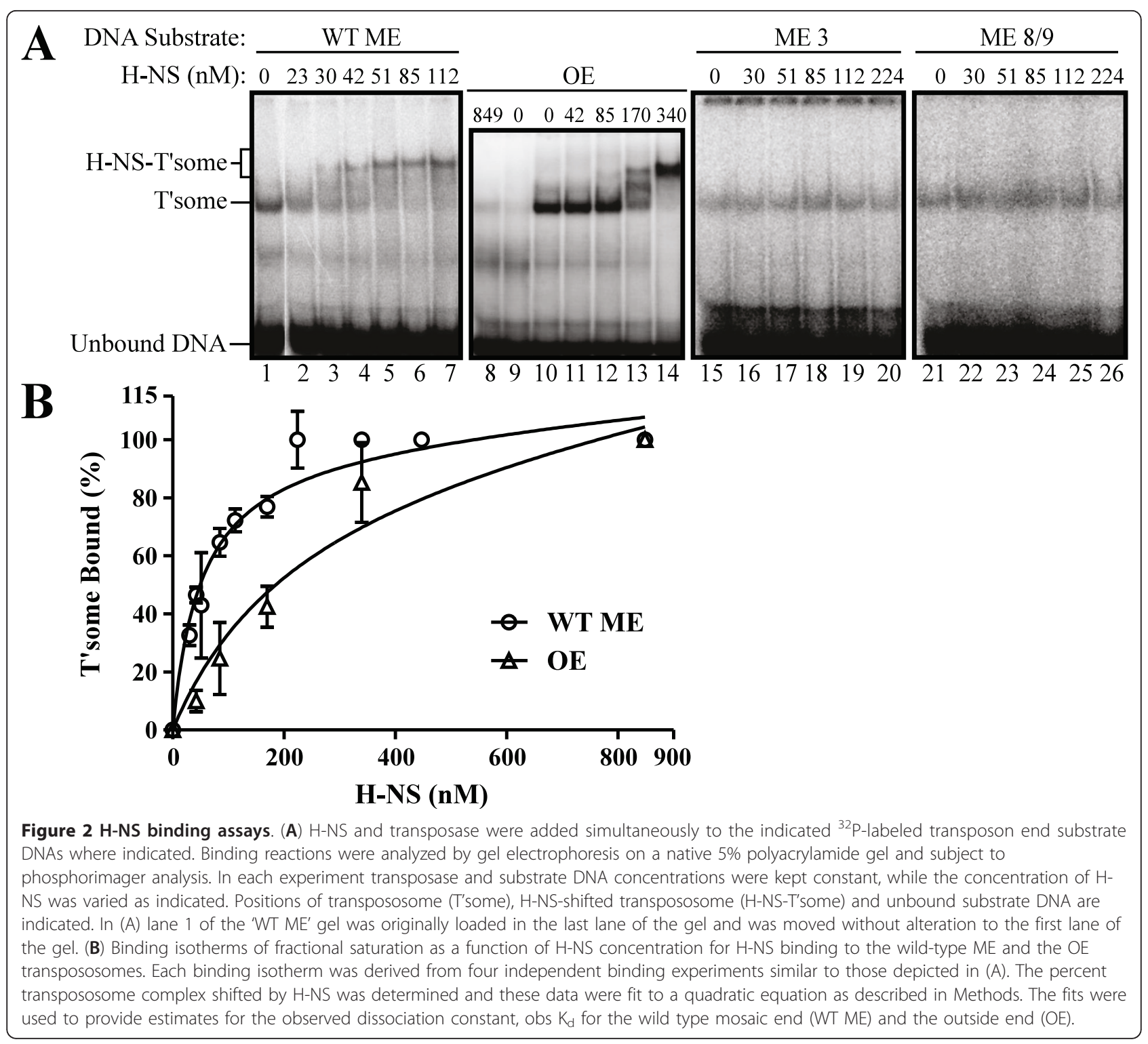

simultaneously mixed $\mathrm{H}-\mathrm{NS}$ and transposase with ${ }^{32} \mathrm{P}$ labeled DNA in buffer lacking a divalent metal ion. These conditions favor the formation of an H-NSbound transpososome, but no chemical steps in transposition take place. Under these conditions, H-NS binding reached saturation for the WT ME and OE transpososomes at concentrations of $112 \mathrm{nM}$ (lane 6) and 340 nM (lane 14), respectively. This is manifested as an upshift in the gel mobility of the respective transpososomes. Notably there was no appreciable binding of $\mathrm{H}$ NS to OE substrate DNA that had not associated with transposase (lane 8). This is indicative of $\mathrm{H}$-NS binding to the transpososome with high specificity. In contrast, under the same reaction conditions we did not detect $\mathrm{H}-\mathrm{NS}$ binding to either transpososomes formed with
ME 3 (lanes 16 to 20) or ME 8/9 (lanes 22 to 26) substrates. This clearly shows that the selected site 1 (ME 3) and site 2 (ME 8/9) mutations drastically impair $\mathrm{H}$ NS binding to the transpososome without interfering with transpososome assembly.

We used binding data from EMSAs shown in Figure 2A and other similar experiments (see Additional file 1) to generate binding curves from which we could calculate $\mathrm{K}_{\mathrm{d}}$ values for the respective $\mathrm{H}$-NS-transpososome interactions (Figure $2 \mathrm{~B}$ ). The $\mathrm{K}_{\mathrm{d}}$ values for these interactions are $51 \pm 6.6 \mathrm{nM}$ for WT ME transpososome and $232 \pm 67.1$ for the OE transpososome.

It should be noted that in the above experiments we do not know if H-NS is binding directly to the transpososome or to a pre-transpososome complex that is 
unstable in the mobility shift assay and/or converts rapidly and irreversibly to a transpososome. For convenience we will, throughout the rest of the paper, refer to the mobility shift results as $\mathrm{H}$-NS binding to the transpososome.

Taken together, the results in this section are consistent with sites 1 and 2 being particularly important for $\mathrm{H}$-NS binding to the transpososome. It remains to be seen if site 3 plays a critical role.

\section{Chemical cross-linking indicates that transposase and $\mathrm{H}$ - NS interact in the context of the transpososome}

The results from our binding studies suggest that H-NS is in close proximity to transposase within the transpososome. Determining if there are direct interactions between transposase and H-NS has mechanistic implications for how H-NS promotes Tn 5 transposition. Only a few proteins have been shown to directly interact with $\mathrm{H}-\mathrm{NS}$ [20-22]. Intriguingly, one of these proteins is the Tn10 transposase. We used the same approach previously reported for the Tn10 system for assessing if Tn5 transposase directly interacts with H-NS [22]. Briefly, we treated transpososome assembly reactions $(+/-\mathrm{H}-\mathrm{NS})$ or purified Tn5 transposase (+/- H-NS) with the protein cross-linking reagent EDC/NHS; this reagent is a zerolength cross-linker that covalently links carboxyl and amino groups. Subsequently, EDC/NHS or mock treated transpososomes were gel-purified and proteins eluted from these gel slices were analyzed by Western blotting and mass spectrometry.

In the Western blot analysis we were looking for a product(s) that in the presence of EDC/NHS had a reduced mobility on an SDS gel relative to transposase (the larger of the two proteins - $60 \mathrm{kDa}$ versus $16 \mathrm{kDa}$ ) and was detected by both antibodies to transposase and H-NS. Note that we used a version of $\operatorname{Tn} 5$ transposase protein containing the T7 gene 10 peptide as an N-terminal epitope tag, thus allowing us to use a commercially available monoclonal antibody for transposase detection. For H-NS detection we used a polyclonal H-NS antibody. After probing a blot with one antibody, the blot was stripped and re-probed with the other antibody.

We show in Figure 3A that EDC/NHS treatment of a transpososome assembly reaction containing $\mathrm{H}-\mathrm{NS}$ yielded two prominent novel products ' $a$ ' and ' $b$ ' that were detected by both antibodies and have an apparent molecular mass greater than the mass of monomeric transposase (lane 5, left panel; lane 6, right panel). Products 'a' and 'b' were not detected in the mock cross-linking reaction where EDC/NHS was omitted (lane 4, left panel; lane 7, right panel) and when H-NS was not included in the assembly reaction (lane 3, left panel; lane 8, right panel). Products ' $a$ ' and ' $b$ ' were also not detected when transposase was mixed with H-NS in the absence of ME DNA (lane 8, left panel; lane 3, right panel), indicating that the appearance of these products is dependent on transpososome formation. However, products ' $a$ ' and ' $b$ ' were detected after micrococcal nuclease treatment of gel-purified EDC/NHS-treated H-NS-transpososomes indicating that these products do not include a DNA component (Figure 3B). Finally, gel slices containing products 'a' and 'b' were digested with trypsin and analyzed using mass spectrometry (matrix-assisted laser desorption/ionizationtime of flight (MALDI-TOF)) (Figure 4). The spectra obtained were compared to a theoretical prediction of mass-to-charge ratios of the resulting peptides from a tryptic digest of transposase and H-NS. Several peaks/peptides corresponding to both proteins were detected in ' $a$ ' samples providing definitive proof that H-NS and transposase are present in a product whose formation is dependent on EDC/NHS treatment. Unfortunately, the mass spectrometry did not provide information regarding residues involved in the cross-linking as there were no peaks/ peptides that were specific to the cross-linked products.

At this point we can only speculate on the precise composition of products ' $a$ ' and ' $b$ ' based on their relative abundances and apparent molecular weights. Product ' $a$ ' is the more abundant product and accordingly is most likely the simplest in terms of composition. With an apparent molecular weight greater than 60 and less than $120 \mathrm{kDa}$, we expect this product includes a monomer of transposase cross-linked to either a monomer of $\mathrm{H}-\mathrm{NS}(76 \mathrm{kDa})$ or a cross-linked dimer of H-NS (92 kDa). Product 'b' could be a cross-linked transposase dimer that is itself cross-linked to an H-NS monomer or a cross-linked H-NS dimer. As $\mathrm{H}-\mathrm{NS}$ readily forms dimers in solution that are efficiently cross-linked by EDC/NHS [12], it is tempting to speculate that each of products 'a' and ' $b$ ' includes a cross-linked $\mathrm{H}$ NS dimer.

Overall the results in this section indicate that within the Tn 5 transpososome H-NS is in close enough proximity to directly interact with transposase. Given that $\mathrm{H}-\mathrm{NS}$ is a DNA-binding protein, this raises the possibility that H-NS may help tether transposase to transposon end sequences by interacting both with transposase and DNA.

\section{Modeling $\mathrm{H}-\mathrm{NS}$ into the Tn5 transpososome structure}

Our biochemical data is most consistent with a dimer of $\mathrm{H}-\mathrm{NS}$ binding the Tn 5 transpososome through interactions with either segment 1 or 2 of the transposon end DNA. In an attempt to integrate this data with the available structural data, we asked if an H-NS dimer could be docked into the existing Tn5 transpososome structure. An NMR structure is available for the H-NS DNA-binding domain, residues 91 to 137 [23]. On the basis of chemical shift experiments, Gordon and co-workers modeled the $\mathrm{H}-\mathrm{NS}$ binding domain into a DNA duplex containing a 5'ATATAT 3' sequence. We used this model of the DNA/ 


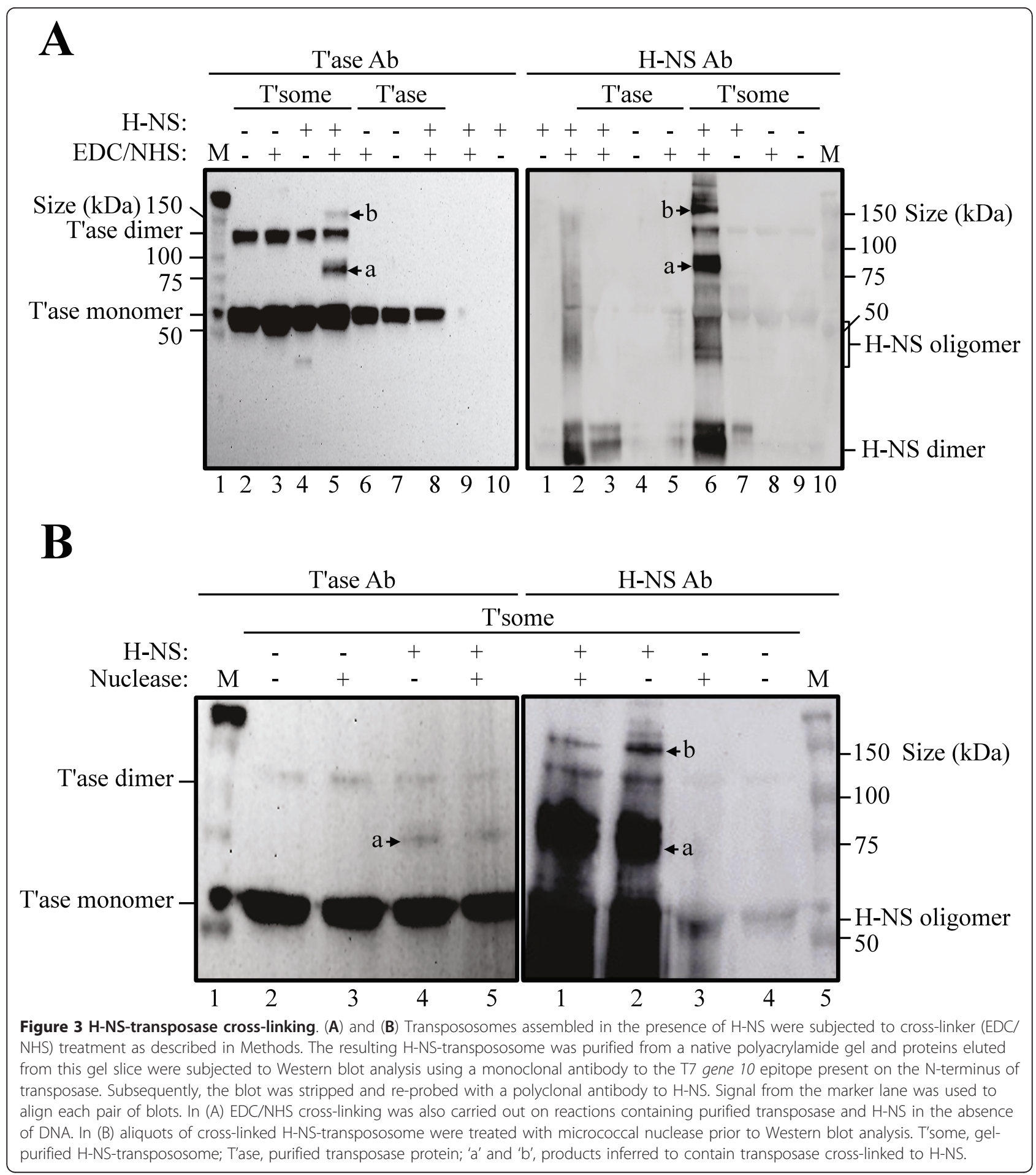

H-NS complex to help position the H-NS DNA-binding domain in the minor groove of the transposon end DNA in the Tn5 transpososome [18], close to positions 8 and 9; recall that mutations at these positions abrogated $\mathrm{H}-\mathrm{NS}$ binding to the transpososome and these residues are within the only A-T rich stretch of the terminal portion of the ME. A second H-NS DNA-binding domain was placed in the equivalent position on the second transposon end. Positioned in this manner, the distance between the two DNA-binding domains is approximately $80 \AA$ (Figure 5).

A crystal structure is available for residues 2 to 82 of the N-terminal oligomerization domain of H-NS [13]. 


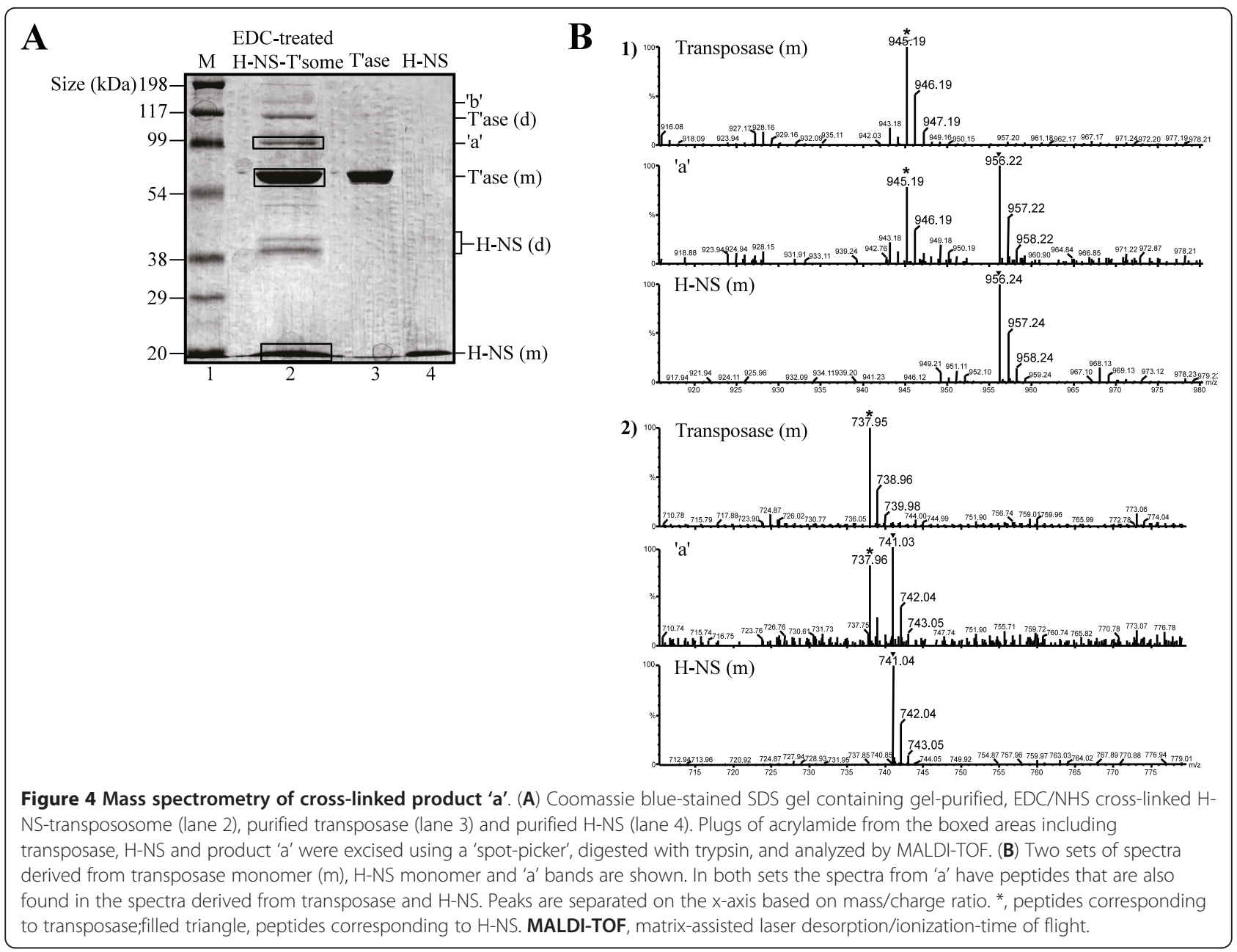

This domain consists of four $\alpha$-helices (H1, H2, H3 and $\mathrm{H} 4)$ that form an extended dimer. The distance between the $\mathrm{C}$-terminal ends of $\mathrm{H} 3$ in the $\mathrm{H}$-NS dimer is approximately $100 \AA$, which is close to the distance of $80 \AA$ between the H-NS DNA-binding domains that were positioned in the Tn 5 transpososome (Figure 5). On this basis, we were able to connect the ends of the H-NS Nterminal domain dimer to the C-terminal DNA-binding domains using the flexible linker, residues 83 to 91 (Figure $5 \mathrm{~A}$ ). In this configuration, the $\mathrm{H}-\mathrm{NS}$ dimer runs across the region of the transpososome implicated in target capture [24]. However, given the flexibility in the position of $\mathrm{H} 4$ and residues 83 to 91 , the $\mathrm{H}-\mathrm{NS}$ dimer could also cross the opposite side of the transpososome (Figure 5B). In this case, $\mathrm{H} 4$ was positioned to pass through the major groove of the transposon end DNA to facilitate connection with the DNA-binding domain. In this configuration $\mathrm{H}-\mathrm{NS}$ could remain bound to the transpososome without interfering with target capture.

There are many possible ways the dimerization domain can be oriented relative to the DNA-binding domain and this orientation will dictate where along the transpososome face $\mathrm{H} 1-\mathrm{H} 3$ is positioned. At present we have chosen an orientation between the domains that limits the number of steric clashes between H1-H3 and either the 'front' or 'back' face of the transposase dimer. While the models are obviously preliminary, we think they are useful because they show that the dimensions of the head-to-head H-NS dimer and the transpososome are compatible for binding in a manner where residues established to be important in transpososome-H-NS interactions (positions 8 and 9 of the transposon ends) are the main anchor points of the structure. It should also be noted that we were unable to dock the H-NS dimer into segment 1 of the transpososome because of steric clashes with transposase.

\section{Mutations within H-NS binding sites 1 and 2 reduce the} ability of H-NS to regulate $\mathrm{Tn} 5$ transposition

Identifying transposon end mutations that reduce $\mathrm{H}-\mathrm{NS}$ binding to the transpososome provided us with an opportunity to test the idea that the role H-NS plays in Tn5 transposition in vivo is a direct result of $\mathrm{H}-\mathrm{NS}$ 

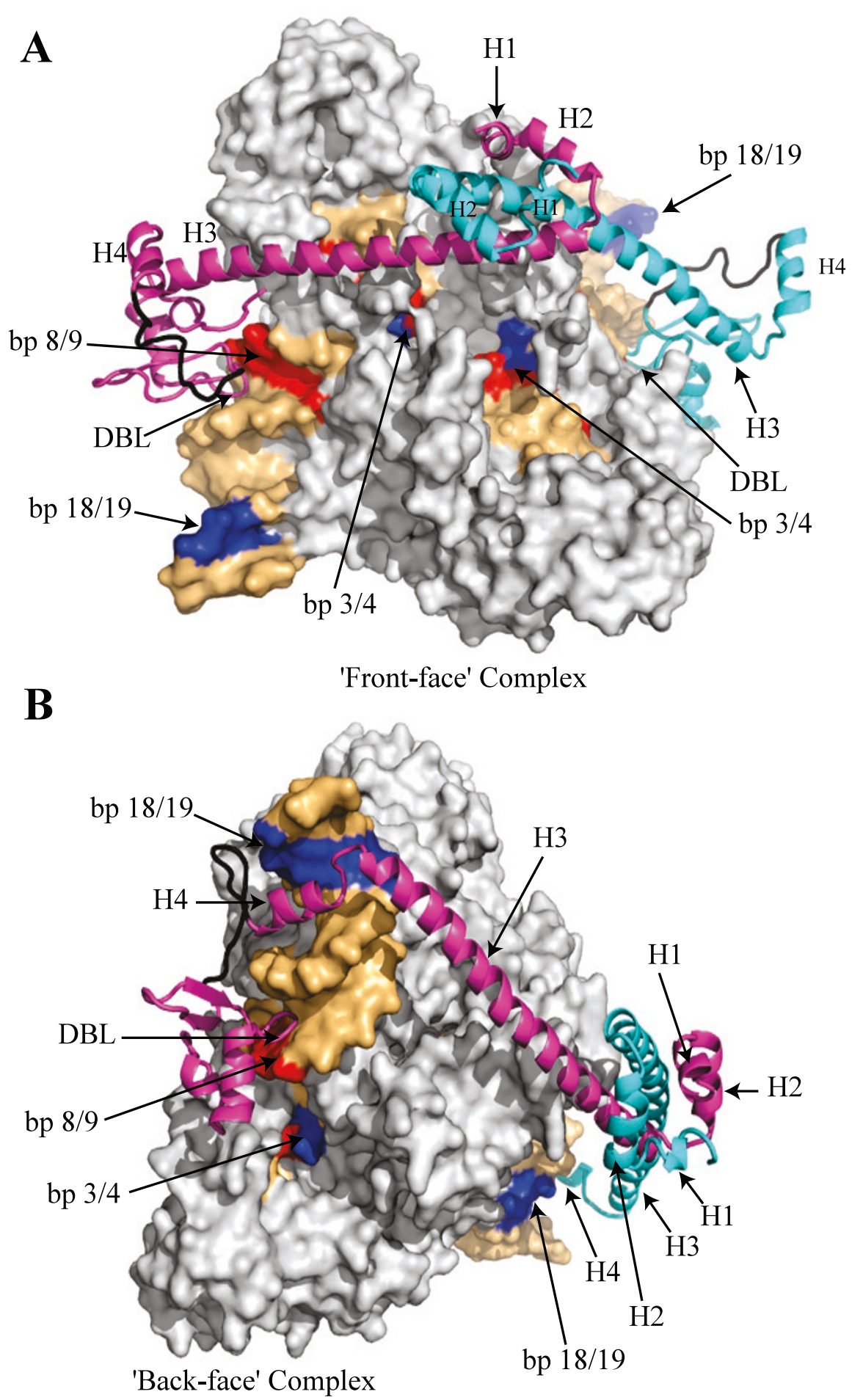

Figure 5 Models for H-NS binding to the Tn5 transpososome. (A) and (B) Models wherein a head-to-head dimer of H-NS is docked to either the 'front' or 'back' face of the transpososome. Helices 1 to 4 of H-NS are labeled, as are specific basepairs in the transposon ends that were mutated in this study (red). Individual monomers of H-NS are in different colors (cyan and magenta) and the residues linking H4 and the DNAbinding domain of H-NS are in black. Tn5 transposase residues are in grey and end sequence is in gold, blue or red. DBL; DNA-binding loop. 
binding to the transpososome, as opposed to being an indirect effect. The latter is a concern given the large number of genes $\mathrm{H}-\mathrm{NS}$ regulates and the pleiotropic nature of hns mutations [10,14]. If $\mathrm{H}-\mathrm{NS}$ regulates Tn5 transposition directly by acting on the transpososome, then mutations that reduce H-NS binding to the transpososome should reduce the sensitivity of transposition to the hns status of the cell. In other words, the roughly three- to five-fold increase in transposition of Tn5 observed in hns + versus $\Delta h n s$ should be reduced when Tn 5 contains a mutation in the transposon ends that reduces $\mathrm{H}-\mathrm{NS}$ binding.

To test our hypothesis we generated a series of plasmids containing mini-Tn 5 transposons with either WT ME's, mutant ME's or OE's. We then measured the transposition frequency of these transposons in isogenic $h n s$ $+/ \Delta h n s$ strains of $E$. coli using a mating out assay. In this experimental set-up transposase (M56A) was provided on a second plasmid under the control of its native promoter - the M56A mutation in transposase ensures that the transposase inhibitor protein is not synthesized making it easier to detect transposition events [25].

The results for this experiment are presented in graphical form in Figure 6 (see also Additional file 2). Each graph shows the range of transposition frequencies obtained for at least three and up to five independent donor strain clones in multiple pair-wise ( $h n s+$ versus $\Delta h n s)$ comparisons for a given transposon (each pair contains results from a single experiment). For each pair the 'fold difference' in transposition observed is indicated on the scatter plot. The results show a trend that generally matches the in vitro H-NS-transpososome binding data for the different substrates. H-NS had the highest affinity for the WT ME and there was a consistent trend of reduced transposition in $\Delta h n s$ versus $h n s+$ (on average 5.6-fold) for this substrate (Figure 6A). Relative to the WT $\mathrm{ME}$, the $\mathrm{OE}$ transpososome had the next highest affinity for H-NS and the OE transposon was slightly less sensitive relative to the WT ME transposon to hns status as transposition was reduced to a lesser degree (on average 3.6fold) in $\Delta h n s$ versus $h n s+$ (Figure 6B). Finally, ME 8/9 and ME 3 transpososomes had the lowest affinity for $\mathrm{H}-$ NS and the hns status of the donor strain had little impact on the transposition frequency of the corresponding transposon substrates (no effect for ME 3 and a two-fold effect for ME 8/9) (Figures 6C and 6D).

It should be noted that each of the mutant ME transposons did transpose at a lower frequency than the WT ME transposon (10-fold for ME 3 and 50-fold for ME 8/9), indicating that the mutations do have a negative impact on transposition independent of their effects on H-NS binding. As an additional control we measured relative copy number levels for the two plasmids present in each strain to ensure that the mating out results did not reflect differences in plasmid copy number. We show in Additional file 3 that plasmid copy number is not affected by hns status.

\section{H-NS status does not influence Tn5 transposase steady- state mRNA levels}

If $\mathrm{H}-\mathrm{NS}$ stimulates Tn 5 transposition by acting directly on the transpososome, we would not expect the difference in transposition frequency in $h n s+$ versus $\Delta h n s$ to be linked to differential expression of the transposase gene. As H-NS is a global regulator of gene expression, it was important to rule out this possibility. We measured steady-state transposase transcript levels by quantitative RT-PCR (qRT-PCR) using RNA isolated from $h n s+$ and $\Delta h n s$ cells used in mating out experiments. The results of this analysis show that transposase expression levels are marginally lower in $h n s+$ versus $\Delta h n s$ cells (Figure 7; also see Additional file 4 for the raw data used to generate Figure 7). The data shown have been normalized to $16 \mathrm{~S}$ rRNA levels measured in the two strains; $16 \mathrm{~S}$ rRNA levels are known not to be influenced by $\mathrm{H}-\mathrm{NS}$ under the conditions used in this work [26]. Thus, the higher transposition frequencies observed in $h n s+$ versus $\Delta h n s$ strains cannot be accounted for by reduced transposase gene expression in $\Delta h n s$.

\section{Discussion}

$\mathrm{H}-\mathrm{NS}$ promotes $\mathrm{Tn} 5$ transpososome formation in vitro through an as yet undefined mechanism that involves incorporation of H-NS into the transpososome [9]. In this work we measured the binding affinity of $\mathrm{H}-\mathrm{NS}$ for the Tn 5 transpososome (or possibly a pre-transpososome transposition complex) and went on to identify, through mutational analysis, basepairs within Tn5 end sequences that play an important role in this interaction. We have also shown through protein-protein cross-linking analysis that H-NS directly interacts with transposase, specifically in the context of the transpososome, and presume that this interaction contributes significantly to the relatively high affinity with which $\mathrm{H}-\mathrm{NS}$ binds the transpososome. Defining mutations within the Tn5 ends that strongly decreased H-NS binding to the transpososome afforded us the opportunity to ask if $\mathrm{H}$ NS promotes Tn 5 transposition in vivo by directly binding the transpososome. We found mutations that inhibited H-NS-transpososome interactions in vitro reduced the sensitivity of transposition reactions to the hns status of the cell, a finding consistent with H-NS acting directly on the transpososome to promote transposition.

\section{Transposon end sequences and transposase provide} determinants for $\mathrm{H}$-NS binding to the $\mathrm{Tn} 5$ transpososome H-NS typically binds AT-rich DNA within promoter sequences independent of interactions with other 


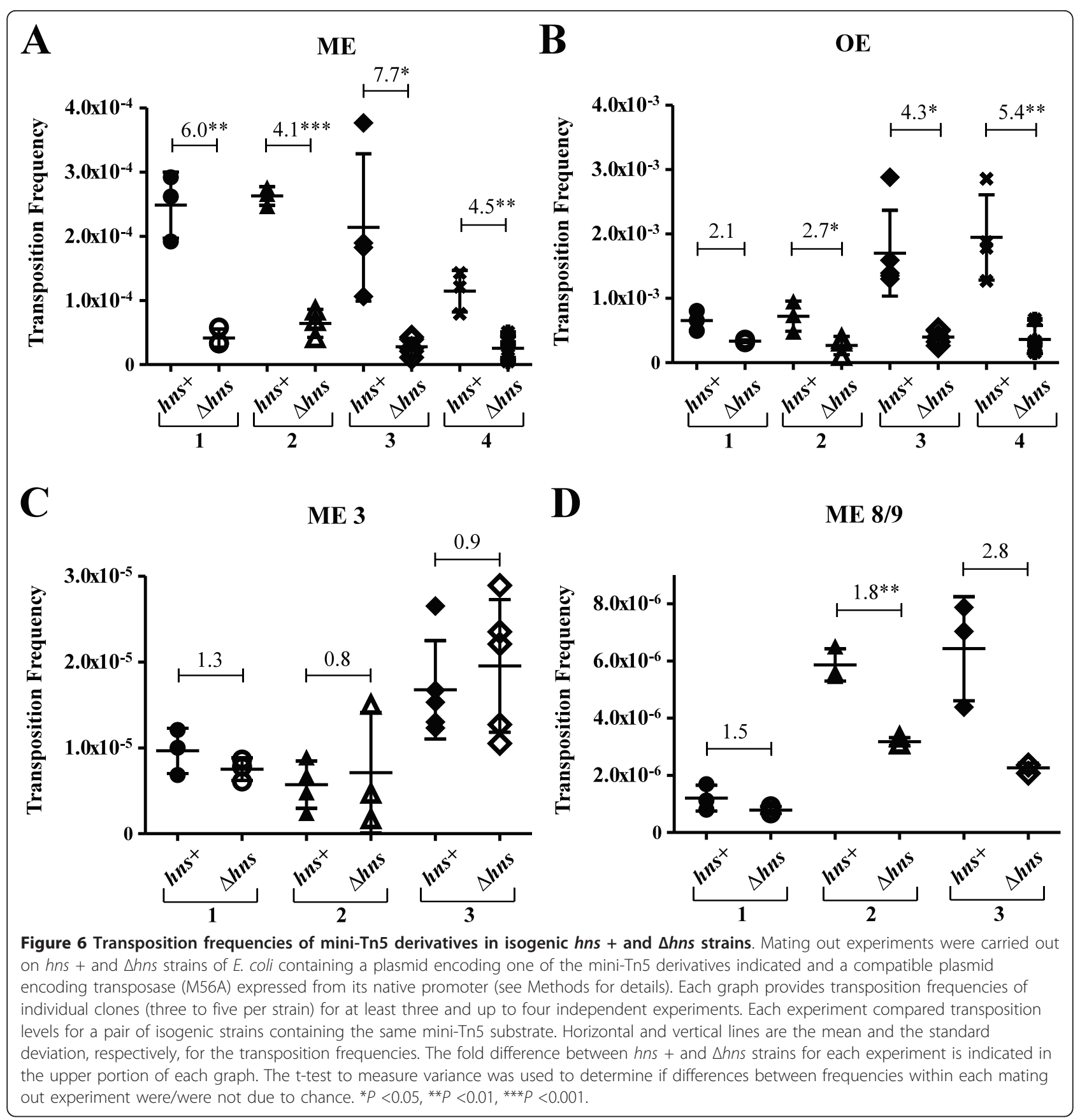

proteins [14]. Within this context a wide range of binding affinities have been reported ranging from micromolar to low nanomolar. One of the tightest interactions reported to date for $E$. coli $\mathrm{H}-\mathrm{NS}$ involves the promoter sequence of the proU operon. A 10 basepair segment within this regulatory sequence was found to bind $\mathrm{H}-\mathrm{NS}$ with a $\mathrm{K}_{\mathrm{d}}$ of $15 \mathrm{nM}$ and to serve as a nucleating sequence for $\mathrm{H}-\mathrm{NS}$ binding to nearby sites possessing intrinsically lower $\mathrm{H}$ NS binding affinities [11]. The highest affinity interaction for $\mathrm{H}-\mathrm{NS}$ reported to date is with a Tn10 transpososome where the reported $K_{d}$ was approximately $0.3 \mathrm{nM}$. In this case, H-NS binding determinants included both transposon end sequences and the Tn10 transposase protein [22]. In the current study we measured the binding strength of H-NS for Tn 5 transpososomes containing different transposon end sequences and report a $K_{d}$ value of approximately $51 \mathrm{nM}$ for the WT ME end sequence. We have also shown that H-NS interacts with Tn5 transposase and accordingly infer that the transposase protein also provides determinants for $\mathrm{H}-\mathrm{NS}$ binding. 


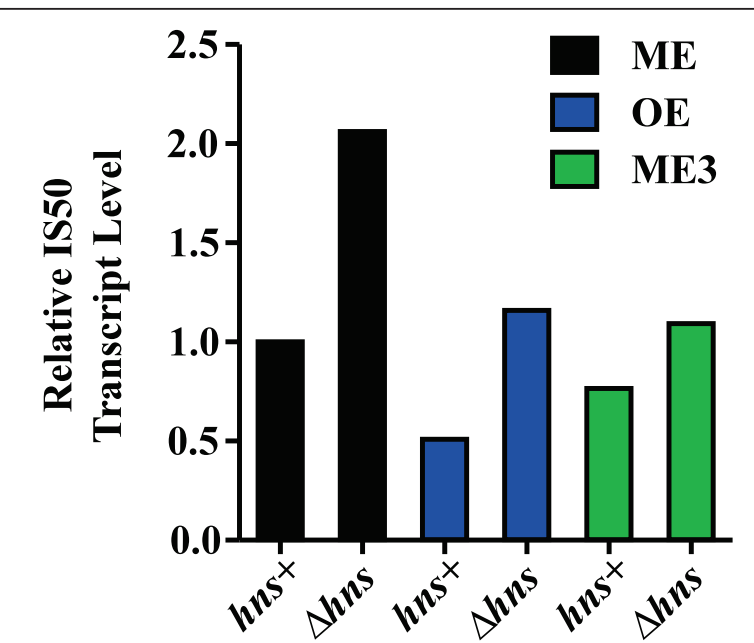

Figure 7 Quantitative RT-PCR analysis of transposase mRNA levels in $h n s+$ and $\Delta h n s$, strains. Total RNA from donor strains used in mating out experiments was isolated at mid-log phase of growth. Roughly equivalent amounts of RNA were reverse transcribed using transposase-specific primers and transposase levels were quantified using real-time RT-PCR (see Methods). We simultaneously measured 165 rRNA levels from hns + and $\Delta h n s$ cells. The relative levels of IS50 transposase transcript presented were normalized to the corresponding levels of $16 \mathrm{~S}$ rRNA transcript. Each normalized value represents an average from four independent clones from a single mating out experiment.

H-NS could promote transpososome assembly by directly binding to the fully-assembled transpososome and stabilizing this structure. Interestingly, in the Tn10 system $\mathrm{H}$-NS binds the transpososome and alters the conformation of this structure in a manner that promotes intermolecular transposition events [8,27]. Given that H-NS interacts directly with the Tn5 transposase protein, it is possible that H-NS could alter the structure of the transposase dimer and in so doing increase transpososome stability. Alternatively, H-NS could promote transposase binding to a transposon end thereby facilitating formation of a single-end complex and/or promoting the pairing of single-end complexes. As transpososomes tend to be inherently stable structures $[28,29]$, we favor the idea that H-NS acts prior to transpososome formation. Consistent with this we have previously shown that $\mathrm{H}-\mathrm{NS}$ can bind a single-end Tn5 transpososome complex [9]. Unfortunately, to this point, a Tn5 single-end complex has only been detected using a mutant form of transposase that is unable to transition into a transpososome [30], so it has not yet been possible to further dissect the role of H-NS in transpososome formation.

The DnaA protein can also bind Tn5 end sequences and could potentially compete with $\mathrm{H}-\mathrm{NS}$ for binding; both the ME and OE contain a single DnaA binding site [31] and this site overlaps putative $\mathrm{H}-\mathrm{NS}$ binding sites 2 and 3 (Figure 1A). Interestingly, it has been reported that DnaA can out-compete transposase for OE binding even after a transpososome has been formed [17]. This raises the possibility that in vivo transposase loading onto an $\mathrm{OE}$ or ME may require an additional host factor such as $\mathrm{H}-\mathrm{NS}$. The approximate $\mathrm{K}_{\mathrm{d}}$ of DnaA for a DNA sequence with a single DnaA site is 30 to $50 \mathrm{nM}$ [32] and keeping in mind our determination of a $\mathrm{K}_{\mathrm{d}}$ of 51 $\mathrm{nM}$ for the H-NS interaction with Tn5 ME-transpososome, it is possible that H-NS would be able to effectively compete with DnaA for ME binding in vivo and thereby significantly contribute to transpososome assembly. Notably, both H-NS and DnaA are highly expressed proteins, although interestingly DnaA expression is growth rate regulated [33].

\section{Point mutations in putative $\mathrm{H}-\mathrm{NS}$ binding sites within ME} sequences greatly reduce $\mathrm{H}-\mathrm{NS}$ binding to the Tn5 transpososome

The results from EMSA studies performed here are consistent with sites 1 and 2 but not site 3 harboring the most critical determinants for H-NS binding. Recent structural studies suggest a straightforward explanation for why site 2 mutations block $\mathrm{H}-\mathrm{NS}$ binding to the Tn5 transpososome. NMR studies are consistent with $\mathrm{H}-\mathrm{NS}$ interacting with DNA through the minor groove over five consecutive residues. In addition, results from a protein-binding microarray study revealed that the major determinant for optimal H-NS binding is the shape of the minor groove, which is dictated by local DNA sequences [23]. Mixed AT-rich sequences or A-tracts within a GC-rich sequence appear to have the optimal minor groove geometry for $\mathrm{H}$ NS binding and GC basepairs in the center of an AT-tract are unfavorable for H-NS binding because of the less optimal electrostatic potential for binding arginine residues, which are present in the DNA-binding motif (an AThook-like loop) of H-NS [34]. Also, the presence of a 2$\mathrm{NH}_{2}$ group on $\mathrm{G}$ that protrudes into the minor groove may provide a steric block to $\mathrm{H}-\mathrm{NS}$ binding. Tn 5 transposase makes extensive contacts in the major groove of the transpososome, including base-specific contacts spanning residues 7 to 13 . In contrast, the minor groove is much more exposed. This includes the only A-T rich segment within the terminal 20 basepairs, which spans residues 8 to 12 [18]. As we have mutated residues 8 and 9 from T:A to $\mathrm{G}: \mathrm{C}$ and $\mathrm{C}: \mathrm{G}$ basepairs respectively, and seen a drastic reduction in $\mathrm{H}-\mathrm{NS}$ binding, it seems likely given the preference of H-NS for AT-rich sequences imbedded in GCrich sequences, that these mutations would directly inhibit $\mathrm{H}$-NS binding. In support of this possibility we were able to dock in silico a head-to-head dimer of H-NS into the Tn 5 transpososome using the exposed minor groove in each of the A-T rich segments of the transposon ends as anchor points for the $\mathrm{C}$ terminal DNA-binding domain of 
$\mathrm{H}-\mathrm{NS}$. It is less obvious why the mutation in putative $\mathrm{H}-$ NS binding site 1 would strongly inhibit $\mathrm{H}-\mathrm{NS}$ binding as there does not appear to be room for $\mathrm{H}-\mathrm{NS}$ to bind this segment of the transpososome.

\section{Genetic evidence that H-NS regulates Tn5 transposition by binding directly to transposition complexes}

Identification of transposon end mutations that strongly interfere with $\mathrm{H}$-NS binding to the Tn 5 transpososome allowed us to test the idea that H-NS up-regulates Tn5 transposition in vivo by acting directly on transposition complexes. Our expectation was that the transposition frequency of a transposon harboring such a mutation(s) would not be influenced by the hns status of the cell. Consistent with the idea that H-NS acts directly on the transpososome to promote Tn5 transposition, we found that the transposition frequency of Tn5 elements harboring end mutations that strongly interfered with $\mathrm{H}$ NS binding to the transpososome in vitro was largely insensitive to hns status. The interpretation of these results is complicated by the fact that the end mutations do more than disrupt H-NS binding to the transpososome as evidenced by the significantly lower transposition frequencies of the mutant versus wild type transposons. It is therefore possible that $\mathrm{H}-\mathrm{NS}$ is unable to stimulate transposition of the mutant transposons because it cannot overcome the 'H-NS independent' defect caused by the mutations. For example, if the ' $\mathrm{H}$ NS independent' defect were downstream of transpososome formation (perhaps one of the chemical steps in transposition), a boost in transpososome formation in the presence of H-NS might not have a significant rescuing effect on transposition. Alternatively, if the ' $\mathrm{H}-\mathrm{NS}$ independent' defect caused by the end mutations was either upstream of transpososome formation (perhaps initial binding of transposase to an end) or at transpososome formation, and was significantly stronger than the positive effect of $\mathrm{H}$-NS on transposition, then the positive effect of H-NS might be masked. We think this latter scenario is unlikely because we did not see a major negative impact of the end mutations on transpososome assembly in vitro in experiments presented in Figure 2. Further testing of the idea that $\mathrm{H}$-NS regulates $\mathrm{Tn} 5$ transposition by directly interacting with the transpososome or pre-transpososome complexes will clearly require biochemical analyses of $\operatorname{Tn} 5$ transpososomes formed in vivo. However, at this point our genetic and in vitro biochemical analyses, as well as our qRT-PCR analysis on H-NS effects on transposase expression, provide an initial level of support for this model.

\section{Conclusions}

As transposons have a major impact on the structure/ composition of bacterial genomes and on gene expression networks, it is important to understand how their mobilization is regulated. The molecular basis of positive regulation of Tn5 transposition by $\mathrm{H}-\mathrm{NS}$ is not well understood and is particularly intriguing because $\mathrm{H}$-NS typically functions as a negative regulator of transcription. A better understanding of how $\mathrm{H}-\mathrm{NS}$ regulates Tn 5 transposition has the potential to define an atypical regulatory mechanism for $\mathrm{H}$-NS. In the current work we have made progress in defining how $\mathrm{H}$-NS interacts with the Tn5 transpososome. We have shown that binding of $\mathrm{H}-\mathrm{NS}$ to the Tn5 transpososome in vitro is dependent on its interactions within the terminal nine residues of the transposon and potentially with the transposase dimer, the protein core of the transpososome. Docking studies carried out in silico are consistent with this interpretation. We have also provided evidence that $\mathrm{H}-\mathrm{NS}$ interactions with basepairs within the terminal nine residues of $\operatorname{Tn} 5$ ends are important for $\mathrm{H}$-NS-mediated regulation of $\operatorname{Tn} 5$ transposition in vivo.

\section{Availability of supporting data}

The data sets supporting the results of this article are included within the article (and its additional files).

\section{Methods}

\section{Plasmids and transposon DNA's}

Plasmid-based mini-Tn5 elements were constructed using a three-fragment cloning strategy. Primers containing a Pst1 site (CW1 and CW2) were designed to the 5' and 3' ends of the kanamycin resistance gene from pNK1182 [35] and a PCR reaction was performed to amplify the $\mathrm{Kan}^{\mathrm{R}}$ fragment. After digestion with PstI the $\mathrm{Kan}^{\mathrm{R}}$ fragment was ligated to the linear fragment of KpnI-digested pTZ18U [36], and to a 20 basepair ME fragment (CW3/4 for WT ME, CW5/6 for OE, CW7/8 for ME 3 and CW9/10 for ME 8/9) containing PstI and KpnI overhangs. The resulting plasmids, pDH626, pDH689, pDH685 and pDH660, contain identical miniTn5 transposons except that the transposon ends were either wild-type ME, OE, ME 3 and ME 8/9 sequences, respectively. To provide a source of $\operatorname{Tn} 5$ transposase on a compatible plasmid to the above transposon substrates, Tn5 transposase DNA from pRZ9905 [37] was cloned into pACYC184 as follows: restriction sites for either HindIII or XbaI were incorporated into primers (CW11 and 12) complementary to the 5' and 3' ends of the Tn5 transposase gene and following amplification and digestion of the transposase fragment with HindIII and $\mathrm{XbaI}$ the transposase fragment was cloned into HindIII/XbaI-digested pACYC184. The transposase gene used contains a mutation that eliminates synthesis of the inhibitor protein, but otherwise is wild-type in sequence. 
Transposon end substrates used for binding assays contain 13 basepairs of donor DNA and 40 basepairs of transposon DNA. These substrates were generated by annealing complementary, gel-purified oligonucleotides (Table 1) and were subsequently 5' end-labelled with T4 polynucleotide kinase (New England Biolabs - Ipswich, MA, USA) and $\gamma^{32}$ P-ATP (Perkin-Elmer - Boston, MA, USA) using standard procedures.

\section{Protein purification}

Tn5 transposase and H-NS were purified as described previously $[38,39]$. Tn 5 transposase concentration was determined using the Bradford assay (Pierce - Rockford, IL, USA) and H-NS concentration was determined using the BCA assay (Pierce).

\section{H-NS binding assay}

Transpososome assembly reactions were performed by mixing ${ }^{32}$ P-labelled transposon end fragments $(2 \mathrm{nM})$ and purified transposase $(200 \mathrm{nM})$ as described previously [9], except that transposase was added at $400 \mathrm{nM}$ in the case of reactions with the ME 8/9 substrate in order to obtain roughly equivalent amounts of transpososome in all in vitro reactions. $\mathrm{H}-\mathrm{NS}$ was added to the reactions at the same time as transposase in varying concentrations (normally $23 \mathrm{nM}$ to $849 \mathrm{nM}$ ) and after incubation for $30 \mathrm{~min}-$ utes at $37^{\circ} \mathrm{C}$ reactions were mixed with load dye and applied to a $5 \%$ native polyacrylamide gel. Gels were run and analyzed as previously described [9]. The typical transpososome yield was about $10 \%$ of input DNA giving a final concentration of $0.2 \mathrm{nM}$ transpososome per assembly reaction. ImageQuant v5.1 software was used to analyze $\mathrm{H}$-NS-bound fractions of transpososome based on the proportion of labelled DNA present in the mobility shifts compared to the overall total labelled DNA in each lane. The equilibrium dissociation constant $\left(\mathrm{K}_{\mathrm{d}}\right)$ was determined using the equation: $\theta^{-1}=1+\left(\mathrm{K}_{\mathrm{d}} /\left[\mathrm{P}_{t}\right]\right)$ where $\theta$ is the fraction of $\mathrm{H}$-NS-bound transpososome and $\mathrm{P}_{t}$ is the total H-NS concentration. At least three independent binding experiments were performed for each transposon

Table 1 Oligonucleotides used in this study ${ }^{\text {a }}$.

\begin{tabular}{|c|c|}
\hline Name & Sequence $\left(5^{\prime}\right.$ to $\left.3^{\prime}\right)$ \\
\hline CW1 & CGCGTTAATCTGCAGCACAGTCGTGATGGC \\
\hline CW2 & CCCTGCGCAGCGCGCAGCTGCAGCCTGAATACGCG \\
\hline CW3 & CTCGACTGTCTCTTATACACATCTAGCGTCCTGAACGGAACCTTCTGCA \\
\hline CW4 & GAAGGTTCCGTTCAGGACGCTAGATGTGTATAAGAGACAGTCGAGGTAC \\
\hline CW5 & CTCGACTGACTCTTATACACAAGTAGCGTCCTGAACGGAACCTTCTGCA \\
\hline CW6 & GAAGGTTCCGTTCAGGACGCTACTTGTGTATAAGAGICAGTCGAGGTAC \\
\hline CW7 & CTCGACTCTCTCTTATACACATCTAGCGTCCTGAACGGAACCTTCTGCA \\
\hline CW8 & GAAGGTTCCGTTCAGGACGCTAGATGTGTATAAGAGAGAGTCGAGGTAC \\
\hline CW9 & CTCGACTGTCTCGCATACACATCTAGCGTCCTGAACGGAACCTTCTGCA \\
\hline CW10 & GAAGGTTCCGTTCAGGACGCTAGATGTGTATGCGAGACAGTCGAGGTAC \\
\hline CW11 & NNNAAGCTTGGGTAACGCCAGGGTTTTCCCACTC \\
\hline CW12 & NNNTCTAGACGCCAAGCTTGCATGCCTGCAGGTC \\
\hline WT ME 53NTS & CCCTGCAGGTCGACTGTCTCTTATACACATCTTGAGTGAGTGAGCATGCA \\
\hline WT ME 53TS & ACATGCATGCTCACTCACTCAAGATGTGTATAAGAGACAGTCGACCTGCAGGG \\
\hline OE 53NTS & CCCTGCAGGTCGACTGACTCTTATACACAAGTTGAGTGAGTGAGCATGCA \\
\hline OE 53TS & ACATGCATGCTCACTCACTCAACTTGTGTATAAGAGICAGTCGACCTGCAGGG \\
\hline ME 3 53NTS & CCCTGCAGGTCGACTCTCTCTTATACACATCTTGAGTGAGTGAGCATGCA \\
\hline ME 3 53TS & ACATGCATGCTCACTCACTCAAGATGTGTATAAGAGACAGTCGACCTGCAGGG \\
\hline ME 8/9 53NTS & CCCTGCAGGTCGACTGTCTCGCATACACATCTTGAGTGAGTGAGCATGCA \\
\hline ME 8/9 53TS & ACATGCATGCTCACTCACTCAAGATGTGTATGCGAGACAGTCGACCTGCAGGG \\
\hline T1TaseF & GACCTCTTAAGATGGTAACGTTCATG \\
\hline T1TaseR & GCCGAAGAGAACACAGATTTAGC \\
\hline T1TaseProbe ${ }^{b}$ & 6FAM-TAACTTCTGCTCTTCATCGTG-MGBNFQ \\
\hline $16 \mathrm{SF}$ & ACCAGGGCTACACACGTGCTA \\
\hline $16 S R$ & TCTCGCGAGGTCGCTTCT \\
\hline 16SProbe ${ }^{b}$ & 6FAM-AATGGCGCATACAAA-MGBNFQ \\
\hline
\end{tabular}

a The first nucleotide of the transposon end sequence ( 1 or +1 position) of each strand is in bold. The mutated nucleotides are underlined. ${ }^{\mathrm{b}} 6 \mathrm{FAM}$ represents 6 carboxyfluorescein. MGBNFQ represents the quencher dye. 
end substrate. Data for WT ME and OE substrates was fit to a quadratic equation using non-linear regression and binding curves were generated using GraphPad Prism v5.0.

\section{Mating out assay}

Mating out assays were performed in isogenic $h n s+$ (DBH33) and $\Delta h n s$ (DBH1) donor strains (Table 1) as previously described [9]. These strains were transformed with a 'transposon substrate' plasmid containing a $\mathrm{Kan}^{\mathrm{R}}$ gene between the transposon ends (either pDH626, pDH689, pDH685 or pDH660) and a compatible 'transposase' plasmid (pDH641). Donor cells were mixed with recipient cells (HB101) and after growth in LB mating mixes were pelleted and resuspended in $0.85 \%$ saline whereupon cells were plated on M9-glucose plates supplemented with leucine, thiamine and streptomycin sulfate $\left(150 \mu \mathrm{g} \mathrm{mL}^{-1}\right)$ for measuring total exconjugants and the above plus kanamycin $\left(50 \mu \mathrm{g} \mathrm{mL}^{-1}\right)$ for measuring transposon hops. Transposition frequencies were calculated by dividing the number of $\mathrm{Kan}^{\mathrm{R}} \mathrm{Sm}^{\mathrm{R}}$ colonies by the number of $\mathrm{Sm}^{\mathrm{R}}$ colonies.

\section{EDC/NHS chemical cross-linking}

Transpososome assembly reactions (100X volume - 1 $\mathrm{mL}$ ) were prepared with unlabeled ME DNA (500 nM), purified transposase (565 nM), and WT H-NS $(1.2 \mu \mathrm{M})$ as previously described [9]. Reactions were concentrated by microfiltration from the initial volume to $0.045 \mathrm{~mL}$ (Millipore [Billerica, MA, USA] Vivaspin 30,000 kDa cutoff). Samples were then treated with $9.5 \mu \mathrm{L}$ of the chemical cross-linker EDC (50 mM) plus NHS (12.5 mM) (both prepared in water) for 2.5 minutes at room temperature. Non-denaturing load dye was added to the cross-linking reactions and samples were applied to a 5\% native polyacrylamide gel. After staining the gel with ethidium bromide the transpososomes and H-NS-bound transpososomes were isolated based on mobility differences. Proteins were eluted out of the gel slices at $42^{\circ} \mathrm{C}$ with $1 \mathrm{~mL}$ of elution buffer $(0.5 \%$ SDS and $1 \mathrm{M}$ sodium acetate), concentrated as described above and subjected to immunoblot analysis as previously described [22]. Purified Tn 5 transposase and $\mathrm{H}-\mathrm{NS}$ were also subjected to EDC/NHS cross-linking as above except that $0.5 \mu \mathrm{g}(1.2$ $\mu \mathrm{M}$ of transposase and $3.6 \mu \mathrm{M}$ of $\mathrm{H}-\mathrm{NS}$ ) of each protein was used either separately or together with or without $2.5 \mu \mathrm{L}$ of the chemical cross-linker EDC (50 mM) plus NHS (12.5 mM) and incubated at room temperature for three minutes. SDS load dye was added and samples were immediately loaded on the SDS protein gel for immunoblot analysis. For complexes that were treated with micrococcal nuclease, the cross-linking protocol was similar except for the following changes. After cross-linker treatment the reactions were stopped with addition of Tris- $\mathrm{HCl} \mathrm{pH} 8.0$ to a final concentration of $500 \mathrm{nM}$.
Micrococcal nuclease (100 units) and $5 \mathrm{mM} \mathrm{CaCl}_{2}$ were added to the reactions and incubated at $37^{\circ} \mathrm{C}$ for $15 \mathrm{~min}$ utes. At the same time, additional samples were mocktreated with only $5 \mathrm{mM} \mathrm{CaCl}_{2}$ and no nuclease. A small amount of each sample $(4 \mu \mathrm{L})$ was removed and analyzed on a $1 \%$ agarose gel to ensure that no DNA remained in the samples treated with the nuclease and that complexes were not disrupted in the mock-treated samples. The remainders of the samples were concentrated as described above to $20 \mu \mathrm{L}$ and loaded on an SDS protein gel.

\section{MALDI-TOF MS analysis of cross-linked species}

A 400x H-NS-transpososome assembly reaction was concentrated to $225 \mu \mathrm{L}$, divided into four equivalent aliquots and each aliquot was treated similarly to above. The crosslinking reactions were quenched by addition of Tris- $\mathrm{HCl}$ $\mathrm{pH} 8.0$ to a final concentration of $500 \mathrm{nM}$ and then applied to a $5 \%$ native polyacrylamide gel. H-NS-transpososome was eluted from the native gel after staining with ethidium bromide and fractions were pooled, concentrated and applied to a single lane of an SDS protein gel, which was stained with Coomassie Blue. Transposase monomer, H-NS monomer and cross-linked product 'a' were gel-isolated from the same lane using an Ettan Spot-picker (GE Healthcare - Mississauga, ON, Canada). In-gel digestion was performed using a MassPREP automated digester station (PerkinElmer). Gel pieces were Coomassie destained using $50 \mathrm{mM}$ ammonium bicarbonate and 50\% acetonitrile, which was followed by protein reduction using 10 $\mathrm{mM}$ dithiotreitol (DTT), alkylation using $55 \mathrm{mM}$ iodoacetamide (IAA), and tryptic digestion. Peptides were extracted using a solution of $1 \%$ formic acid and $2 \%$ acetonitrile and lyophilized. Prior to mass spectrometry analysis, dried peptide samples were re-dissolved in 50\% acetonitrile and $0.1 \%$ trifluoroacetic acid (TFA). A saturated solution of the MALDI matrix, $\alpha$-cyano-4-hydroxycinnamic acid (CHCA), was prepared in $67 \%$ acetonitrile and $0.05 \%$ TFA, diluted to $70 \%$ saturation, mixed with the samples at $1: 1$ ratio $(\mathrm{v} / \mathrm{v})$ and $1 \mu \mathrm{L}$ samples were spotted on the MALDI target. Mass spectrometry data were obtained using a 4700 Proteomics Analyzer, MALDI TOF (Applied Biosystems, Foster City, CA, USA). Data acquisition and data processing were done using MassLynx 3.5 Mass Spectrometry Software (Waters), respectively. The instrument is equipped with a $355 \mathrm{~nm} \mathrm{Nd:YAG} \mathrm{laser;} \mathrm{the} \mathrm{laser} \mathrm{rate} \mathrm{is}$ $200 \mathrm{~Hz}$. Reflectron and linear positive ion modes were used. Reflectron mode was calibrated at 50 ppm mass tolerance. Each mass spectrum was collected as a sum of 1,000 shots. Theoretical masses of the peptides produced from a tryptic digestion of Tn 5 transposase and $\mathrm{H}-\mathrm{NS}$ were calculated using PROWL's ProteinInfo peptide mass prediction tool (Rockefeller University, Laboratory of Mass Spectrometry and Gaseous Ion Chemistry). 


\section{Quantitative RT-PCR and analysis}

A total of 1 to $2 \mathrm{~mL}$ of cells were removed from donor strain cultures immediately before the remaining $1 \mathrm{~mL}$ were mixed with recipient strain for the mating out. The cells were gently centrifuged $(4000 \times \mathrm{g}$ for four minutes), resuspended in $200 \mu \mathrm{L}$ of RNALater (Ambion - Burlington, ON, Canada and incubated at $4^{\circ} \mathrm{C}$ overnight. The following day, RNA was extracted from each sample using the RNeasy Mini-kit (Qiagen - Streetsville, ON, Canada). The quality and quantity of the final RNA samples were assessed using agarose gel electrophoresis and a NanoDrop spectrophotometer (IMPLEN) to measure $A_{260}, A_{260 / 230}$ and $A_{260 / 280}$ ratios. A portion of the RNA was treated with the RNase-free TURBO DNAfree Kit (Applied Biosystems) as per instructions for typical amounts of contaminating genomic DNA. The resulting RNA was quantified again as above to ensure $\mathrm{A}_{260 / 230}$ and $\mathrm{A}_{260 / 280}$ ratios were in the range of 1.5 to 2.0. RT-PCR was performed with a portion of this RNA ( 0.5 to $1 \mu \mathrm{g})$ using the protocol and reagents in the High Capacity RT-PCR Kit (Applied Biosystems). The final cDNA concentrations of 25 to $50 \mathrm{ng} \mu \mathrm{L}^{-1}$ (depending on the starting amount of RNA) were diluted to 25 ng $\mu \mathrm{L}^{-1}$ (if necessary) for use in real-time PCR reactions. TaqMan primers and probes (see Table 1) were designed using the Applied Biosystem Primer Express 2.0 software to the very 5 ' end (nucleotides 5 to 87 ) of the transposase transcript and the endogenous control 16S rRNA. 16S RNA was used as a 'normalizing' control for $\Delta h n s$ strains in other work [26]. Reactions for realtime PCR were done in $20 \mu \mathrm{L}$ volumes in 384 well clear plates using the protocol in the TaqMan Gene Expression MasterMix guide (Applied Biosystems). Three biological replicates were tested per strain and three technical replicates were used for real-time PCR for each biological replicate. Appropriate control reactions were conducted where RNA was omitted, or reverse transcriptase was omitted for each RNA sample. Control real-time PCR reactions containing no cDNA (1X TE replacement) and no TaqMan 'enzyme mix' were also conducted. Reactions were run using standard cycle parameters on an Applied Biosystems 7900-HT RealTime System. The Pfaffl mathematical model of relative quantification was used to determine the relative amounts of transposase mRNA [40]. Relative amount $=$ $\left(E_{\text {transposase }}\right)^{\Delta \mathrm{Ct} \text { transposase }} /\left(E_{16 \mathrm{~S}}\right)^{\Delta \mathrm{Ct} 16 \mathrm{~S}}$ where $E$ is the PCR amplification efficiencies of the transposase transcript and $16 \mathrm{~S}$ rRNA transcript that were determined by creating several standard curves with known diluted target concentrations $\left(E=10^{(-1 / \text { slope })}\right)$. The amplification efficiencies for the transposase target and $16 \mathrm{~S}$ gene using these primers and probes were determined to be 1.99 and 1.92 , respectively. $\Delta \mathrm{Ct}$ of transposase or $16 \mathrm{~S}$ represents the average sample $\mathrm{Ct}$ for each condition subtracted from the average Ct of the reference condition to which all samples will be quantified relative to (that is, NK5830F' (hns + strains) transformed with pDH533-4 (WT ME DNA)).

\section{Modeling H-NS-transpososome complex}

The H-NS DNA-binding domain was manually positioned into the minor groove of the transposon end DNA, using the H-NS DNA-binding domain in complex with duplex DNA as a guide [23]. The symmetry of the Tn 5 transpososome was used to place a second H-NS DNA-binding domain in an equivalent position on the second transposon end. For the 'front face' complex, the structure of the H-NS N-terminal domain (NTD) dimer [PDB:3NR7] was manually positioned to place the Cterminal ends close to the DNA-binding domains. Residues 83 to 90 were added to the $\mathrm{C}$-terminal end of the $\mathrm{H}-\mathrm{NS}$ NTD and the connection between the two domains was made using the loop-building utility in SwissPDBViewer [41]. A similar process was used to position the H-NS dimer on the opposite side ('back face') of the transpososome, but in this case $\mathrm{H} 4$ was manually positioned into the major groove of the transposon end DNA to facilitate the connection between the $\mathrm{N}$ - and $\mathrm{C}$-terminal domains. Minor adjustments and corrections to the stereochemistry were made using Coot [42].

\section{Additional material}

Additional file 1: H-NS binding assays. Titration of H-NS into WT ME and $\mathrm{OE}$ transpososomes for $\mathrm{K}_{\mathrm{d}}$ calculations.

Additional file 2: Mating out frequencies. Comparison of transposition frequencies in isogenic hns strains.

Additional file 3: Plasmid copy number determination in mating out experiment. Agarose gel analysis of plasmid DNA preparations made from strains used in mating out experiments.

Additional file 4: Relative levels of Tn5 transposase transcript in hns strains as measured by qRT-PCR. Standard curve used to determine the relative amounts of transposase mRNA.

\section{Abbreviations}

EDC: 1-ethyl-3-(3-dimethylaminopropyl)carbodiimide; EMSA: electrophoretic mobility shift assay; IE: inside end; ME: mosaic end; NHS: N-

hydroxysuccinimide; RT-PCR: reverse transcriptase polymerase chain reaction; T'some: transpososome.

\section{Acknowledgements}

We thank J. Ross for reading the manuscript and for discussions. We also thank W. Reznikoff for providing Tn5 plasmids, D. Jin for providing H-NS antibody, and W. Navarre for providing the coordinates of the H-NS DNAbinding domain in complex with DNA. This work was supported by a Canadian Institutes of Health Research Grant (FRN 11281) to D.B.H, an NSERC Discovery grant to B.H.S. and an NSERC PGS D studentship to C.R.W.

\section{Authors' contributions}

CRW performed all of the experiments and helped to draft the manuscript. BS performed the structure-modeling studies and helped to draft the 
manuscript. DBH conceived of the study, participated in its design and coordination, and helped to draft the manuscript. All authors read and approved the final manuscript.

\section{Competing interests}

The authors declare that they have no competing interests.

Received: 16 January 2012 Accepted: 13 April 2012

Published: 13 April 2012

\section{References}

1. Curcio MJ, Derbyshire KM: The outs and ins of transposition: from mu to kangaroo. Nat Rev Mol Cell Biol 2003, 4:865-877.

2. Nagy Z, Chandler M: Regulation of transposition in bacteria. Res Microbiol 2004, 155:387-398.

3. Roberts D, Hoopes BC, McClure WR, Kleckner N: IS10 transposition is regulated by, DNA adenine methylation. Cell 1985, 43:117-130.

4. Yin JC, Krebs MP, Reznikoff WS: Effect of dam methylation on Tn5 transposition. J Mol Biol 1988, 199:35-45.

5. Signon $L$, Kleckner N: Negative and positive regulation of Tn10/IS10promoted, recombination by IHF: two distinguishable processes inhibit transposition off of multicopy plasmid replicons and activate chromosomal events that favor evolution of new transposons. Genes Dev 1995, 9:1123-1136.

6. Jain C, Kleckner N: IS10 mRNA stability and steady state levels in Escherichia coli:, indirect effects of translation and role of rne function. Mol Microbiol 1993, 9:233-247.

7. Ross JA, Wardle SJ, Haniford DB: Tn10/IS10 transposition is downregulated at the, level of transposase expression by the RNAbinding protein Hfq. Mol Microbiol 2010, 78:607-621.

8. Wardle SJ, O'Carroll M, Derbyshire KM, Haniford DB: The global regulator $\mathrm{H}-\mathrm{NS}$ acts, directly on the transpososome to promote $\mathrm{Tn} 10$ transposition. Genes Dev 2005, 19:2224-2235.

9. Whitfield CR, Wardle SJ, Haniford DB: The global bacterial regulator H-NS promotes, transpososome formation and transposition in the Tn5 system. Nucleic Acids Res 2009, 37:309-321.

10. Dorman CJ: H-NS: a universal regulator for a dynamic genome. Nat Rev Microbiol 2004, 2:391-400.

11. Bouffartigues E, Buckle M, Badaut C, Travers A, Rimsky S: H-NS cooperative binding, to high-affinity sites in a regulatory element results in transcriptional silencing. Nat Struct Mol Biol 2007, 14:441-448.

12. Badaut C, Williams R, Arluison V, Bouffartigues E, Robert B, Buc H, Rimsky S: The, degree of oligomerization of the H-NS nucleoid structuring protein is related to specific binding to DNA. J Biol Chem 2002, 277:41657-41666.

13. Arold ST, Leonard PG, Parkinson GN, Ladbury JE: H-NS forms a superhelical protein, scaffold for DNA condensation. Proc Natl Acad Sci USA 2011, 107:15728-15732.

14. Navarre WW, McClelland M, Libby SJ, Fang FC: Silencing of xenogeneic DNA by $\mathrm{H}-$, NS-facilitation of lateral gene transfer in bacteria by a defense system that recognizes foreign DNA. Genes Dev 2007, 21:1456-1471.

15. Hommais F, Krin E, Laurent-Winter C, Soutourina O, Malpertuy A, Le Caer JP, Danchin A, Bertin P: Large-scale monitoring of pleiotropic regulation of gene expression by the, prokaryotic nucleoid-associated protein, H-NS. Mol Microbiol 2001, 40:20-36.

16. Ono S, Goldberg MD, Olsson T, Esposito D, Hinton JC, Ladbury JE: H-NS is a part of, a thermally controlled mechanism for bacterial gene regulation. Biochem J 2005, 391:203-213.

17. Reznikoff WS: Tn5 transposition. Mob DNA 2002, II:403-422.

18. Davies DR, Goryshin IY, Reznikoff WS, Rayment I: Three-dimensional structure of, the Tn5 synaptic complex transposition intermediate. Science 2000, 289:77-85.

19. Zhou M, Bhasin A, Reznikoff WS: Molecular genetic analysis of transposase-end, DNA sequence recognition: cooperativity of three adjacent base-pairs in specific interaction with a mutant Tn5 transposase. J Mol Biol 1998, 276:913-925.

20. Donato GM, Kawula TH: Enhanced binding of altered H-NS protein to flagellar, rotor protein FliG causes increased flagellar rotational speed and hypermotility in Escherichia coli. J Biol Chem 1998, 273:24030-24036.
21. Ali SS, Beckett E, Bae SJ, Navarre WW: The 5.5 protein of phage T7 inhibits $\mathrm{H}-\mathrm{NS}$, through interactions with the central oligomerization domain. J Bacteriol 2011, 193:4881-4892.

22. Wardle SJ, Chan A, Haniford DB: H-NS binds with high affinity to the Tn10, transpososome and promotes transpososome stabilization. Nucleic Acids Res 2009, 37:6148-6160.

23. Gordon BR, Li Y, Cote A, Weirauch MT, Ding P, Hughes TR, Navarre WW, Xia B, Liu J: Structural basis for recognition of AT-rich DNA by unrelated xenogeneic silencing, proteins. Proc Natl Acad Sci USA 2011, 108:10690-10695.

24. Gradman RJ, Ptacin JL, Bhasin A, Reznikoff WS, Goryshin IY: A bifunctional DNA, binding region in Tn5 transposase. Mol Microbiol 2008, 67:528-540.

25. Wiegand TW, Reznikoff WS: Characterization of two hypertransposing Tn5, mutants. J Bacteriol 1992, 174:1229-1239.

26. Moreira RN, Dressaire C, Domingues $S$, Arraiano CM: A new target for an old, regulator: $\mathrm{H}-\mathrm{NS}$ represses transcription of bolA morphogene by direct binding to both promoters. Biochem Biophys Res Commun 411:50-55.

27. Singh RK, Liburd J, Wardle SJ, Haniford DB: The nucleoid binding protein $\mathrm{H}-\mathrm{NS}$ acts, as an anti-channeling factor to favor intermolecular Tn10 transposition and dissemination. J Mol Biol 2008, 37:950-962.

28. Surette MG, Buch SJ, Chaconas G: Transpososomes: stable protein-DNA complexes, involved in the in vitro transposition of bacteriophage $\mathrm{Mu}$ DNA. Cell 1987, 49:253-262.

29. Haniford DB, Benjamin HW, Kleckner N: Kinetic and structural analysis of a cleaved, donor intermediate and a strand transfer intermediate in Tn10 transposition. Cell 1991, 64:171-179.

30. Steiniger-White M, Reznikoff WS: The C-terminal alpha helix of Tn5 transposase is, required for synaptic complex formation. J Biol Chem 2000, 275:23127-23133.

31. Yin JC, Reznikoff WS: dnaA, an essential host gene, and Tn5 transposition. J Bacteriol 1987, 169:4637-4645.

32. Schaper S, Messer W: Interaction of the initiator protein DnaA of Escherichia coli, with its DNA target. J Biol Chem 1995, 270:17622-17626.

33. Chiaramello $A E$, Zyskind JW: Expression of Escherichia coli dnaA and mioC genes, as a function of growth rate. J Bacteriol 1989, 171:4272-4280.

34. Rohs R, West SM, Sosinsky A, Liu P, Mann RS, Honig B: The role of DNA shape in, protein-DNA recognition. Nature 2009, 461:1248-1253.

35. Benjamin HW, Kleckner N: Excision of Tn10 from the donor site during, transposition occurs by flush double-strand cleavages at the transposon termini. Proc Natl Acad Sci USA 1992, 89:4648-4652.

36. Mead DA, Szczesna-Skorupa E, Kemper B: Single-stranded DNA 'blue' T7 promoter, plasmids: a versatile tandem promoter system for cloning and protein engineering. Protein Eng 1986, 1:67-74.

37. Naumann TA, Reznikoff WS: Trans catalysis in Tn5 transposition. Proc Natl Acad Sci USA 2000, 97:8944-8949.

38. Peterson $G$, Reznikoff $W$ : Tn5 transposase active site mutations suggest position of, donor backbone DNA in synaptic complex. J Biol Chem 2003, 278:1904-1909.

39. Zhang A, Rimsky S, Reaban ME, Buc H, Belfort M: Escherichia coli protein analogs, StpA and H-NS: regulatory loops, similar and disparate effects on nucleic acid dynamics. EMBO J 1996, 15:1340-1349.

40. Pfaffl MW: A new mathematical model for relative quantification in realtime RT-PCR. Nucleic Acids Res 2001, 29:e45.

41. Guex N, Peitsch MC: SWISS-MODEL and the Swiss-PdbViewer: an environment, for comparative protein modeling. Electrophoresis 1997, 18:2714-2723.

42. Emsley P, Cowtan K: Coot: model-building tools for molecular graphics. Acta Crystallogr 2004, 60:2126-2132.

\section{doi:10.1186/1759-8753-3-7}

Cite this article as: Whitfield et al:: Identification of basepairs within Tn5 termini that are critical sfor H-NS binding to the transpososome and regulation of Tn5 transposition. Mobile DNA 2012 3:7. 